\title{
Comparison of standard prophylactic and preemptive therapeutic low molecular weight heparin treatments in hospitalized patients with COVID-19
}

\author{
Copur B ${ }^{1}$, Surme $\mathrm{S}^{1}$, Sayili $\mathrm{U}^{2}$, Tuncer $\mathrm{G}^{1}$, Zerdali E ${ }^{1}$, Yazla $\mathrm{M}^{1}$, Nakir IY ${ }^{1}$, Buyukyazgan $\mathrm{A}^{1}$, \\ Kurt-Cinar AR ${ }^{1}$, Balli $\mathrm{H}^{1}$, Kurekci $\mathrm{Y}^{1}$, Pehlivanoglu $\mathrm{F}^{1}$, Sengoz $\mathrm{G}^{1}$
}

Department of Infectious Diseases and Clinical Microbiology, Haseki Training and Research Hospital, Istanbul, Turkey. betul_sadic@hotmail.com

\begin{abstract}
INTRODUCTION: Anticoagulant treatment approach in patients with COVID-19 is not well studied and not standardized. We aimed to compare the effects of standard prophylactic and pre-emptive therapeutic LowMolecular-weight Heparin (LMWH) treatment approaches on mortality in patients with COVID-19.

PATIENTS AND METHODS: This retrospective and single-centre study includes patients aged $\geq 18$ years, who were diagnosed with COVID-19 and treated with LMWH during the hospital stay. Therapeutic dose of LMWH was defined as $1 \mathrm{mg} / \mathrm{kg}$ subcutaneously twice daily and prophylactic dose of LMWH was defined as $40 \mathrm{mg}$ subcutaneously once daily.

RESULTS: Among the 336 patients diagnosed with COVID-19 pneumonia, 115 patients, who received LMWH were included in the study. The mean age was $58.6 \pm 13.3$ and $58(50.4 \%)$ of the patients were male. Sixty-nine $(60 \%)$ of the patients were treated with prophylactic and $46(40 \%)$ therapeutic LMWH. In-hospital mortality was not different between patients treated therapeutic LMWH and prophylactic LMWH by the multivariate regression analysis $(\mathrm{OR}=2.187,95 \% \mathrm{Cl} 0.484-9.880, \mathrm{p}=0.309)$ and the propensity score modelling (OR=1.586, 95\% Cl 0.400-6.289, $\mathrm{p}=0.512$.)

CONCLUSION: Clinicians should consider the potential risks and benefits of standard prophylactic and pre-emptive therapeutic LMWH. Therefore, anticoagulant therapy should be individualized in patients with COVID-19 (Tab. 3, Ref. 28). Text in PDF www.elis.sk

KEY WORDS: anticoagulant therapy, COVID-19, Low-molecular-weight heparin (LMWH), mortality, outcome.
\end{abstract}

\section{Introduction}

The disease caused by a newly discovered beta coronavirus, SARS-CoV-2, has been named the Coronavirus Disease 2019 (COVID-19) by the World Health Organization (WHO) (1). After the first COVID-19 case reported in Wuhan, China in December 2019 , the disease spread rapidly and was declared as a pandemic by the WHO (2). COVID-19 has caused mortality and morbidity, especially multiple complications. Coagulopathy is one of the serious complications of COVID-19. Autopsy results demonstrated deep vein thrombosis, pulmonary microthrombi and embolisms in patients with COVID-19 (3). As seen in Coronavirus infections, the systemic inflammatory response seen in severe COVID-19 patients may result in coagulation disorders. Any imbalances between procoagulant, anticoagulant, and fibrinolytic homeostatic mechanisms may cause hypercoagulability or bleeding $(4,5)$. Moreover, studies suggested that anticoagulants reduce mortality

${ }^{1}$ Department of Infectious Diseases and Clinical Microbiology, Haseki Training and Research Hospital, Istanbul, Turkey, and ${ }^{2}$ Karakopru District Health Directorate, Republic of Turkey Ministry of Health, Sanliurfa, Turkey

Address for correspondence: B. Copur, MD, Department of Infectious Diseases and Clinical Microbiology, Haseki Training and Research Hospital, TR-34098, Istanbul, Turkey. in the patients with severe disease $(6,7)$. Despite the lack of information about coagulopathy mechanism, coagulation disorders in COVID-19 are certain and therefore, anticoagulant treatment is mostly commenced prophylactically and therapeutically in COVID-19 patients. However, anticoagulant treatment approach in the patients with COVID-19 is not well studied and not standardized $(8,9,10)$. Therefore, in this study, we aimed to compare the effects of standard prophylactic and preemptive therapeutic Low Molecular Weight Heparin (LMWH) treatment approaches on mortality in the patients with COVID-19.

\section{Patients and methods}

\section{Study design and patients}

This retrospective and single-centre study includes patients aged $\geq 18$ years, who were diagnosed with COVID- 19 and treated at least three days with LMWH during the hospital stay between March 11 and April 11, 2020. Exclusion criteria were as follows: 1) patients with negative results of SARS-CoV-2 by reverse-transcriptase real-time polymerase chain reaction. 2) patients, who were not treated with LMWH during their inpatient stay; 3) patients receiving other forms of anticoagulant; 4) patients, who received therapeutic LMWH for a thrombotic indication. 
Therapeutic dose of LMWH was defined as $1 \mathrm{mg} / \mathrm{kg}$ subcutaneously twice daily and prophylactic dose of LMWH was defined as $40 \mathrm{mg}$ subcutaneously once daily. Prophylactic and therapeutic LMWH were administered by the trained physicians based on the disease severity and d-dimer levels. However, there was no definite protocol for the anticoagulant treatment regimen. As increased D-dimer levels were mostly found in patients with thrombotic complications, patients with increased D-dimer levels were prophylactically or therapeutically treated with LMWH to reduce thrombotic events and mortality (6-12). Mortality was defined as all-cause in-hospital death.

\section{Data collection}

The demographic data, age, gender, underlying diseases, symptoms, physical examination findings, laboratory parameters and radiological results, the treatments and outcomes were recorded via a follow-up datasheet. We recorded body temperature, respiratory rate, heart rate, arterial blood pressure, oxygen saturations at the time of first presentation to hospital and calculated the National Early Warning Score 2 (NEWS2) score to identify the severity of the disease. Laboratory results and radiological examinations were included if performed within 24 hours of admission and after LMWH treatment.

\section{Statistical analysis}

Data were analysed using the Statistical Package for the Social Sciences, IBM SPSS, version 21 (SPSS Inc, Chicago, USA). Demographic and clinical features were described by mean \pm standard deviation, median (minimum-maximum) for continuous variables, and frequency (n) and percentages (\%) for categorical variables. Chi-Square test and Fisher's exact test were used to compare the differences in proportions of categorical variables between the groups. Kolmogorov-Smirnov test was used for normal distribution. Independent Samples t-test and Mann-Whitney U-test were used for comparison of continuous variables between the two independent groups. The value of $\mathrm{p}<$ 0.05 was accepted to be statistically significant. To compare the mortality between the two groups of LMWH dosage, univariate and multivariate analyses were performed. Additionally, logistic regression analysis with a propensity score adjustment was performed to mitigate biases attributable to covariate imbalances in the group characteristics.
Tab. 1. The demographic and clinical characteristics of COVID-19 patients.

\begin{tabular}{|c|c|c|c|c|c|c|c|}
\hline & \multicolumn{2}{|c|}{ In Total } & \multicolumn{2}{|c|}{$\begin{array}{l}\text { Prophylactic } \\
\text { LMWH }\end{array}$} & \multicolumn{2}{|c|}{$\begin{array}{l}\text { Therapeutic } \\
\text { LMWH }\end{array}$} & \multirow[t]{2}{*}{$p$} \\
\hline & $\mathrm{n}$ & $\%$ & $\mathrm{n}$ & $\%$ & $\mathrm{n}$ & $\%$ & \\
\hline Number of patients & 115 & 100 & 69 & 60 & 46 & 40 & \\
\hline \multicolumn{8}{|l|}{ Age } \\
\hline $\begin{array}{l}\text { Mean } \pm \text { sd } \\
\text { Median }\end{array}$ & \multicolumn{2}{|c|}{$\begin{array}{l}56.8 \pm 13.3 \\
58(20-80) \\
\end{array}$} & \multicolumn{2}{|c|}{$\begin{array}{l}56.9 \pm 14.5 \\
57(20-80)\end{array}$} & \multicolumn{2}{|c|}{$\begin{array}{c}56.8 \pm 11.4 \\
59.5(27-79)\end{array}$} & $0.975^{c}$ \\
\hline $\begin{array}{l}\text { Gender } \\
\text { Male } \\
\text { Female } \\
\end{array}$ & $\begin{array}{l}58 \\
57 \\
\end{array}$ & $\begin{array}{l}50.4 \\
49.6 \\
\end{array}$ & $\begin{array}{l}28 \\
41 \\
\end{array}$ & $\begin{array}{l}40.6 \\
59.4\end{array}$ & $\begin{array}{l}30 \\
16 \\
\end{array}$ & $\begin{array}{l}65.2 \\
34.8 \\
\end{array}$ & $0.010^{a}$ \\
\hline $\begin{array}{l}\text { Underlying diseases } \\
\text { COPD } \\
\text { Diabetes mellitus } \\
\text { Hypertension } \\
\end{array}$ & $\begin{array}{c}77 \\
3 \\
38 \\
44 \\
\end{array}$ & $\begin{array}{c}67.0 \\
2.6 \\
33.0 \\
38.3 \\
\end{array}$ & $\begin{array}{c}45 \\
1 \\
21 \\
29\end{array}$ & $\begin{array}{c}65.2 \\
1.4 \\
30.4 \\
42.0 \\
\end{array}$ & $\begin{array}{c}32 \\
2 \\
17 \\
15 \\
\end{array}$ & $\begin{array}{c}69.6 \\
4.3 \\
37.0 \\
32.6 \\
\end{array}$ & $\begin{array}{l}0.627^{\mathrm{a}} \\
0.563^{\mathrm{b}} \\
0.466^{\mathrm{a}} \\
0.309^{\mathrm{a}} \\
\end{array}$ \\
\hline \multicolumn{8}{|l|}{ Sign and symptoms } \\
\hline $\begin{array}{l}\text { Fever } \\
\text { Cough } \\
\text { Dyspnea } \\
\text { Myalgia } \\
\text { Arthralgia } \\
\end{array}$ & $\begin{array}{c}52 \\
84 \\
51 \\
13 \\
4 \\
\end{array}$ & $\begin{array}{l}45.2 \\
73.0 \\
44.3 \\
11.3 \\
3.5 \\
\end{array}$ & $\begin{array}{c}30 \\
51 \\
31 \\
7 \\
3 \\
\end{array}$ & $\begin{array}{c}43.5 \\
73.9 \\
44.9 \\
10.1 \\
4.3 \\
\end{array}$ & $\begin{array}{c}22 \\
33 \\
20 \\
6 \\
1 \\
\end{array}$ & $\begin{array}{c}47.8 \\
71.7 \\
43.5 \\
13.0 \\
2.2 \\
\end{array}$ & $\begin{array}{l}0.646^{\mathrm{a}} \\
0.797^{\mathrm{a}} \\
0.878^{\mathrm{a}} \\
0.631^{\mathrm{a}} \\
0.649^{\mathrm{b}} \\
\end{array}$ \\
\hline $\begin{array}{l}\text { Body temperature } \\
\text { mean } \\
\text { median (min-max) } \\
\end{array}$ & \multicolumn{2}{|c|}{$\begin{array}{c}36.9 \pm 0.7 \\
36.7(36-39.1) \\
\end{array}$} & \multicolumn{2}{|c|}{$\begin{array}{c}36.8 \pm 0.60 \\
36.7(36.0-38.7) \\
\end{array}$} & \multicolumn{2}{|c|}{$\begin{array}{c}37.02 \pm 0.74 \\
37(36.0-39.1) \\
\end{array}$} & $0.078^{\mathrm{d}}$ \\
\hline $\begin{array}{l}\text { Respiratory rate/ minute } \\
\text { mean } \\
\text { median (min-max) } \\
\end{array}$ & \multicolumn{2}{|c|}{$\begin{array}{c}22.7 \pm 5.1 \\
22(15-40)\end{array}$} & \multicolumn{2}{|c|}{$\begin{array}{c}21.5 \pm 3.3 \\
20(16-35) \\
\end{array}$} & \multicolumn{2}{|c|}{$\begin{array}{c}24.5 \pm 6.6 \\
22(15-40) \\
\end{array}$} & $0.010^{d}$ \\
\hline $\begin{array}{l}\text { Heart rate/minute } \\
\text { mean } \\
\text { median (min-max) } \\
\end{array}$ & \multicolumn{2}{|c|}{$\begin{array}{c}89.1 \pm 13.8 \\
88(57-138) \\
\end{array}$} & \multicolumn{2}{|c|}{$\begin{array}{c}87.7 \pm 13.5 \\
86(57-138) \\
\end{array}$} & \multicolumn{2}{|c|}{$\begin{array}{c}91.5 \pm 14.2 \\
89(64-120) \\
\end{array}$} & $0.137^{d}$ \\
\hline $\begin{array}{l}\mathrm{SpO} 2 \\
\text { mean } \\
\text { median (min-max) } \\
\end{array}$ & \multicolumn{2}{|c|}{$\begin{array}{c}91.2 \pm 6.3 \\
93(65-99) \\
\end{array}$} & \multicolumn{2}{|c|}{$\begin{array}{c}92.2 \pm 4.4 \\
93(76-99) \\
\end{array}$} & \multicolumn{2}{|c|}{$\begin{array}{c}89.8 \pm 8.3 \\
92(65-99)\end{array}$} & $0.393^{d}$ \\
\hline NEWS $2<7$ & 62 & 53.9 & 55 & 79.7 & 7 & 15.2 & $<0.001^{\mathrm{a}}$ \\
\hline NEWS $2 \geq 7$ & 53 & 46.1 & 14 & 20.3 & 39 & 84.8 & \\
\hline
\end{tabular}

$\mathrm{COPD}=$ Chronic obstructive pulmonary disease, $\mathrm{SpO} 2=$ peripheral capillary oxygen saturation, min $=$ minimum; $\max =\operatorname{maximum}$, NEWS2 $=$ The National Early Warning Score 2, ${ }^{\mathbf{a}}$ Chi-Square Test, ${ }^{\mathbf{b}}$ Fisher's Exact Test, ${ }^{\mathbf{c}}$ Independent. Samples T Test, ${ }^{\mathbf{d}}$ Mann-Whitney U Test.

\section{Results}

\section{General characteristics}

Among the 336 patients diagnosed with COVID-19 pneumonia, 115 patients, who received LMWH were included in the study. Sixty-nine $(60 \%)$ of the patients were treated with prophylactic and 46 (40\%) with therapeutic LMWH. The mean age was 58.6 \pm 13.3 and $58(50.4 \%)$ of the patients were male. Among patients, who received therapeutic LMWH, male gender was more common $(\mathrm{p}=0.010)$. There was no significant difference in both groups in terms of age and underlying diseases. There were also no significant differences in COVID-19 pneumonia onset symptoms, with the inclusion of fever (temperature $\geq 37.4{ }^{\circ} \mathrm{C}$ ), cough, dyspnoea, myalgia, and arthralgia (Tab. 1). However, only respiratory rate was higher in the therapeutic group $(\mathrm{p}=0.010)$. Creactive protein and $\mathrm{D}$-dimer levels were significantly higher in the patients receiving therapeutic doses of LMWH (respectively; $\mathrm{p}=0.012, \mathrm{p}<0.015)$. There was no significant difference in the conventional therapies between the groups (Tab. 2).

\section{Risk of mortality}

The length of hospital stay $(13.4 \pm 6.1$ days vs $10.9 \pm 6.8$ days, $\mathrm{p}=0.004)$, the need for mechanical ventilation $(50.0 \%$ vs $14.5 \%, \mathrm{p}<0.001)$, the admission to inten- 
Tab. 2. Laboratory parameters, Treatments and Clinical outcomes of COVID-19 patients.

\begin{tabular}{|c|c|c|c|c|c|c|c|}
\hline & \multicolumn{2}{|c|}{ In total } & \multicolumn{2}{|c|}{$\begin{array}{c}\text { Prophylactic } \\
\text { LMWH }\end{array}$} & \multicolumn{2}{|c|}{$\begin{array}{c}\text { Therapeutic } \\
\text { LMWH }\end{array}$} & \multirow[t]{2}{*}{$\mathrm{p}$} \\
\hline & mean & $\mathrm{sd}$ & mean & $\mathrm{sd}$ & mean & $\mathrm{sd}$ & \\
\hline \multicolumn{8}{|l|}{ Laboratory parameters } \\
\hline Leukocyte $(/ \mu \mathrm{L})$ & 6218 & 2384 & 6375 & 2442 & 5984 & 2301 & $0.352^{\mathrm{d}}$ \\
\hline Neutrophile $(/ \mu \mathrm{L})$ & 4408 & 2056 & 4477 & 2061 & 4304 & 2066 & $0.723^{d}$ \\
\hline Lymphocyte $(/ \mu \mathrm{L})$ & 1256 & 563.0 & 1334 & 647.3 & 1140 & 382.9 & $0.208^{d}$ \\
\hline Platelet (x103) & 192.9 & 72.3 & 196.9 & 70.3 & 187.0 & 75.7 & $0.269^{d}$ \\
\hline CK (IU/L) & 236.6 & 370.6 & 225.1 & 406.4 & 253.3 & 315.4 & $0.024^{d}$ \\
\hline Albumin (g/L) & 34.5 & 5.0 & 35.8 & 4.2 & 32.7 & 5.4 & $0.004^{c}$ \\
\hline Ferritin (ng/mL) & 291.7 & 244.2 & 265.1 & 211.5 & 338.1 & 290.2 & $0.295^{\mathrm{d}}$ \\
\hline $\mathrm{CRP}(\mathrm{mg} / \mathrm{L})$ & 79.2 & 67.0 & 64.1 & 50.6 & 101.7 & 81.4 & $0.012^{d}$ \\
\hline Procalcitonin $(\mu \mathrm{g} / \mathrm{L})$ & 0.3 & 0.5 & 0.1 & 0.2 & 0.5 & 0.8 & $<0.001^{d}$ \\
\hline D-dimer $(\mu \mathrm{g} / \mathrm{L})$ & 1.3 & 3.0 & 0.8 & 0.4 & 2.2 & 4.8 & $0.015^{d}$ \\
\hline \multicolumn{8}{|l|}{ Treatments } \\
\hline Hydroxychloroquine & 106 & 92.2 & 63 & 91.3 & 43 & 93.5 & $0.671^{\mathrm{a}}$ \\
\hline Oseltamivir & 96 & 83.5 & 56 & 81.2 & 40 & 87.0 & $0.412^{\mathrm{a}}$ \\
\hline Azithromycin or Clarithromycin & 112 & 97.4 & 68 & 98.6 & 44 & 95.7 & $0.563^{\mathrm{b}}$ \\
\hline Ceftriaxone & 98 & 85.2 & 56 & 81.2 & 42 & 91.3 & $0.133^{\mathrm{a}}$ \\
\hline Lopinavir/Ritonavir & 32 & 27.8 & 16 & 23.2 & 16 & 34.8 & $0.174^{\mathrm{a}}$ \\
\hline Favipravir & 30 & 26.1 & 14 & 20.3 & 16 & 34.8 & $0.083^{\mathrm{a}}$ \\
\hline Tosilizumab & 5 & 4.3 & 2 & 2.9 & 3 & 6.5 & $0.388^{\mathbf{b}}$ \\
\hline Corticosteroid & 25 & 21.7 & 11 & 15.9 & 14 & 30.4 & $0.065^{\mathrm{a}}$ \\
\hline \multicolumn{8}{|l|}{ Clinical outcomes } \\
\hline Non-invasive ventilation & 35 & 30.4 & 11 & 15.9 & 24 & 52.2 & $<0.001^{\mathrm{a}}$ \\
\hline Invasive ventilation & 33 & 28.7 & 10 & 14.5 & 23 & 50.0 & $<0.001^{\mathrm{a}}$ \\
\hline ICU & 36 & 31.3 & 13 & 18.8 & 23 & 50.0 & $<0.001^{\mathrm{a}}$ \\
\hline Death & 25 & 21.7 & 5 & 7.2 & 20 & 43.5 & $<0.001^{\mathrm{a}}$ \\
\hline $\begin{array}{c}\text { LOS in hospital } \\
\quad(\text { mean } \pm \text { std })\end{array}$ & \multicolumn{2}{|c|}{$11.9 \pm 6.6$} & \multicolumn{2}{|c|}{$10.9 \pm 6.8$} & \multicolumn{2}{|c|}{$13.4 \pm 6.1$} & $0.004^{\mathrm{d}}$ \\
\hline
\end{tabular}

$\mathrm{CRP}=\mathrm{C}$-reactive protein; $\mathrm{ICU}=$ Intensive care unite $\mathrm{LOS}=$ Length of stay; $\mathrm{sd}=$ standard deviation; $\mathrm{a}=$ Chi-Square Test; b=Fisher's Exact Test; $\mathrm{c}=$ Independent Samplest Test; $\mathrm{d}=$ Mann-Whitney U Test

Tab. 3. Univariate and multivariate analyses for mortality in patients with COVID-19.

\begin{tabular}{lccccccc}
\hline & \multicolumn{3}{c}{ Univariate Analysis } & & \multicolumn{3}{c}{ Multivariate Analysis } \\
\cline { 2 - 3 } \cline { 7 - 8 } & OR & $(95 \% \mathrm{CI})$ & $\mathrm{p}$ value & & OR & $(95 \% \mathrm{CI})$ & $\mathrm{p}$ value \\
\hline Male Gender & 2.54 & $0.995-6.483$ & 0.051 & & 1.457 & $0.421-5.042$ & 0.552 \\
\hline Age & 1.025 & $0.989-1.062$ & 0.183 & & 1.050 & $0.992-1.111$ & 0.092 \\
\hline C-reactive protein & 1.016 & $1.008-1.025$ & $<\mathbf{0 . 0 0 1}$ & & 1.014 & $1.004-1.023$ & $\mathbf{0 . 0 0 5}$ \\
\hline Therapeutic LMWH & 9.846 & $3.341-29.017$ & $<\mathbf{0 . 0 0 1}$ & & 2.187 & $0.484-9.880$ & 0.309 \\
\hline NEWS $\geq 7$ & 53.143 & $6.844-412.6$ & $<\mathbf{0 . 0 0 1}$ & & 21.486 & $2.213-208.647$ & $\mathbf{0 . 0 0 8}$ \\
\hline
\end{tabular}

LMWH $=$ Low Molecular Weight Heparin, NEWS2 = The National Early Warning Score 2

sive care unit (ICU) $(50.0 \%$ vs $18.8 \%, \mathrm{p}=0.001)$ and mortality $(43.5 \%$ vs $7.2 \%, \mathrm{p}<0.001)$ were significantly higher in the therapeutic group treated with LMWH compared to those treated with prophylactic LMWH (Tab. 2). Male gender, dyspnoea, low oxygen saturation, high body temperature, increased respiratory rate, receiving lopinavir/ritonavir, favipravir, corticosteroid therapy, high level of C-reactive protein, procalcitonin, urea, low level of albumin, longer duration of hospital stay, the need for ICU and mechanical ventilation, and receiving prophylactic LMWH were associated with mortality $(\mathrm{p}<0.05)$. In univariate analysis, inhospital mortality was higher in the therapeutic LMWH group (OR $=9.846,95 \%$ CI 3.341-29.017, p < 0.001). Mortality was not different between therapeutic and prophylactic LMWH groups when we adjusted gender, age, C-reactive protein and NEWS2 (OR = 2.187, 95\% CI 0.484-9.880, $\mathrm{p}=0.309$ ) (Tab. 3). This difference remained after adjusting for gender, CRP, D-dimer, and NEWS2 by propensity score $(\mathrm{OR}=1.586,95 \% \mathrm{CI}$ $0.400-6.289, \mathrm{p}=0.512)$.

\section{Discussion}

In our study, mortality ( $43.5 \%$ vs 7.2 $\%, \mathrm{p}<0.001)$ was significantly higher in the therapeutic group treated with LMWH compared to those treated with prophylactic LMWH. However, mortality was not different between patients treated with therapeutic LMWH and prophylactic LMWH by the multivariate regression analysis $(\mathrm{OR}=$ $2.187,95 \%$ CI $0.484-9.880, \mathrm{p}=0.309)$ and the propensity score modelling $(\mathrm{OR}=1.586$, $95 \%$ CI $0.400-6.289, \mathrm{p}=0.512$ ).

There is an increasing number of studies indicating that LMWH is effective in reducing mortality in patients with COVID-19 $(6,7)$. However, only a few studies compared therapeutic and prophylactic doses of LMWH treatments (13-19). Whereas some studies showed advantages $(7,11)$ and disadvantages (12-16) of therapeutic LMWH, others found no difference on clinical outcomes/mortality (17-19). Paranjpe et al reported that patients, who received anticoagulants were more likely to need an invasive mechanical ventilation $(29.8 \%$ vs $8.1 \%, \mathrm{p}<0.001)$, and among the mechanically ventilated patients, the mortality rate was lower in the patients, who were treated with anticoagulant than those, who were not treated with anticoagulant $(29.1 \%$ vs $62.7 \%$ ) (7). Additionally, Paoliss et al reported that receiving therapeutic LMWH therapy was associated with a lower in-hospital mortality compared to the prophylactic LMWH (13). In contrast, in the study of Motta et al, the mortality was 2.3 times higher in patients, who received therapeutic dose LMWH than those, who received prophylactic dose LMWH (14). Musoke et al emphasized the higher mortality and increased bleeding complications in those receiving therapeutic dose anticoagulant therapy (15). In the study of Hsu et al, 30-day mortality rate was statistically higher in the patients receiving therapeutic anticoagulation (40\%), when compared to the standard (15\%) and high-intensity prophylaxis cohorts $(6 \%)$ (16). The randomized clinical trial (17) showed that therapeutic LMWH improved gas exchange and decreased the ratio of unsuccessful weaning from the ventilator. In the same study, although the mortality rate was not significantly different, it was found to be higher in those receiving therapeutic LMWH than those receiving prophylactic LMWH, what is consistent with our study. Nadkarni et al. showed that when compared toh prophylactic anticoagulant, therapeutic anticoagulant was associated with a lower mortality, 
although not statistically significant (18). Also, Klok et al found that there was no difference in mortality in the patients receiving therapeutic anticoagulation, although they found an increase in thromboembolic events (19). Additionally, anticoagulation treatment has limited (20) or not significant (21) effect on thrombosis in the patients with COVID-19.

Thromboembolic events and cytokine storm release caused by the development of coagulopathy have significant impact on COVID-19 prognosis $(22,23)$. The dysfunction of endothelial cells induced by infection, resulting in an excessive thrombin production and inhibition of fibrinolysis, indicates hypercoagulability in the patients with COVID-19. In the pathogenesis of severe acute respiratory syndrome associated with Coronavirus, high plasma inflammatory cytokines (interleukin 1, 6, 8, and 12), tumour necrosis factor, interferons, and chemokines takes place in the severe storm $(24,25)$. Some studies showed that anticoagulant treatment had positive effects on clinical outcomes and laboratory parameters in the patients with COVID-19 $(6,7,13,26,27)$. Tang et al. suggested that COVID-19 severity was associated with D-dimer and Fibrin degradation products (28). Also, they found that LMWH was associated with a better prognosis in severe COVID-19 patients with elevated D-dimer levels or meeting Sepsis-Induced Coagulopathy criteria (6). LMWH is known to have not only anticoagulant, but also anti-inflammatory effects. Shi et al showed that LMWH reduced percentage of lymphocytes d-dimer and IL-6 levels in patients with COVID-19 (26). Also, Yormaz et al showed that the count of lymphocytes $(\mathrm{OR}=0.356, \mathrm{p}<0.001)$, D-dimer $(\mathrm{OR}=0.974, \mathrm{p}<0.001)$ and CRP levels $(\mathrm{OR}=0.628, \mathrm{p}<0.001)$ were significantly improved in the LMWH group, as compared to the control group (27).

This study has several strengths. Firstly, multiple comorbidities and different types of variables such as: vital signs, laboratory parameters and radiological findings were included in the multivariate regression analysis. Secondly, we excluded patients with laboratory un-confirmed COVID-19. Our study had also several limitations. Firstly, it was retrospectively conducted in a singlecentre. Secondly, this study had a small sample size and a control group was not included. The generalizability of our results may be limited. Third, physicians might tend to recommend therapeutic treatment for severe cases during the first month of the pandemic. However, we used propensity score modelling to make the outcomes comparable in the two cohorts, by adjusting for covariates, because LMWH treatment was not randomly assigned.

\section{Conclusion}

In conclusion, we did not find an association between therapeutic LMWH and mortality in hospitalized patients with COVID-19 even after adjusting for covariates. Clinicians should consider the potential risks and benefits of standard prophylactic and preemptive therapeutic LMWH. Therefore, anticoagulant therapy should be individualized in patients with COVID-19. However, we need new large-scale studies and randomized controlled trials providing important information to better understand anticoagulant therapy in the patients with COVID-19.

\section{References}

1. World Health Organization. WHO Director-General's remarks at the media briefing on 2019-nCoV on 11 February 2020. Available from: https://www.who.int/dg/speeches/detail/who-director-general-s-remarksat-the-media-briefing-on-2019-ncov-on-11-february-2020. Last accessed 21 November, 2020.

2. World Health Organization. WHO Director-General's opening remarks at the media briefing on COVID-19 - 11 March 2020. Available from: https://www.who.int/dg/speeches/detail/who-director-general-sopening-remarks-at-the-media-briefing-on-covid-19---11-march-2020. Last accessed 21 November, 2020.

3. Wichmann D, Sperhake JP, Lütgehetmann M et al. Autopsy Findings and Venous Thromboembolism in Patients With COVID-19: A Prospective Cohort Study. Ann Intern Med 2020; 173 (4): 268-277. DOI: 10.7326/M20-2003.

4. Giannis D, Ziogas IA, Gianni P. Coagulation disorders in coronavirus infected patients: COVID-19, SARS-CoV-1, MERS-CoV and lessons from the past. J Clin Virol 2020; 127: 104362. DOI: 10.1016/j.jcv.2020.104362.

5. Conti P, Ronconi G, Caraffa A et al. Induction of pro-inflammatory cytokines (IL-1 and IL-6) and lung inflammation by Coronavirus-19 (COVI19 or SARS-CoV-2): anti-inflammatory strategies. J Biol Regul Homeost Agents 2020; 34 (2): 327-331. DOI: 10.23812/CONTI-E.

6. Tang N, Bai H, Chen X, Gong J, Li D, Sun Z. Anticoagulant treatment is associated with decreased mortality in severe coronavirus disease 2019 patients with coagulopathy. J Thromb Haemost 2020; 18 (5):1094-1099. DOI: $10.1111 /$ jth. 14817 .

7. Paranjpe I, Fuster V, Lala A et al. Association of Treatment Dose Anticoagulation With In-Hospital Survival Among Hospitalized Patients With COVID-19. J Am Coll Cardiol 2020; 76 (1):122-124. DOI: 10.1016/j. jacc.2020.05.001.

8. Moores LK, Tritschler T, Brosnahan S et al. Prevention, Diagnosis, and Treatment of VTE in Patients With Coronavirus Disease 2019: CHEST Guideline and Expert Panel Report. Chest 2020; 158 (3):1143-1163. DOI: 10.1016/j.chest.2020.05.559.

9. Susen S, Tacquard CA, Godon A et al. GIHP and GFHT. Prevention of thrombotic risk in hospitalized patients with COVID-19 and hemostasis monitoring. Crit Care 2020; 24 (1): 364. DOI: 10.1186 /s13054020-03000-7.

10. Spyropoulos AC, Levy JH, Ageno W et al. Subcommittee on Perioperative, Critical Care Thrombosis, Haemostasis of the Scientific, Standardization Committee of the International Society on Thrombosis and Haemostasis. Scientific and Standardization Committee communication: Clinical guidance on the diagnosis, prevention, and treatment of venous thromboembolism in hospitalized patients with COVID-19. J Thromb Haemost 2020; 18 (8): 1859-1865. DOI: 10.1111/jth.14929.

11. Secco E, Pasqualetto MC, Bombardini T, Picano E, Rigo F. A possible benefit from therapeutic anticoagulation in patients with coronavirus disease 2019: the Dolo hospital experience in Veneto, Italy. Kardiol Pol 2020; 78 (9): 919-921. DOI: 10.33963/KP.15489.

12. Artifoni M, Danic G, Gautier G et al. Systematic assessment of venous thromboembolism in COVID-19 patients receiving thromboprophylaxis: incidence and role of D-dimer as predictive factors. J Thromb Thrombolysis 2020; 50 (1): 211-216. DOI: 10.1007/s11239-020-02146-z.

13. Paolisso P, Bergamaschi L, D'Angelo EC et al. Preliminary Experience With Low Molecular Weight Heparin Strategy in COVID-19 Patients. Front Pharmacol 2020; 11: 1124. DOI: 10.3389/fphar.2020.01124. 
$626-630$

14. Motta JK, Ogunnaike RO, Shah R et al. Clinical Outcomes with the Use of Prophylactic Versus Therapeutic Anticoagulation in Coronavirus Disease 2019. Crit Care Explor 2020; 2 (12): e0309. DOI: 10.1097/ CCE.0000000000000309.

15. Musoke N, Lo KB, Albano $\mathbf{J}$ et al. Anticoagulation and bleeding risk in patients with COVID-19. Thromb Res 2020; 196: 227-230. DOI: 10.1016/j.thromres.2020.08.035.

16. Hsu A, Liu Y, Zayac AS, Olszewski AJ, Reagan JL. Intensity of anticoagulation and survival in patients hospitalized with COVID-19 pneumonia. Thromb Res 2020; 196: 375-378. DOI: 10.1016/j. thromres.2020.09.030.

17. Lemos ACB, do Espírito Santo DA, Salvetti MC et al. Therapeutic versus prophylactic anticoagulation for severe COVID-19: A randomized phase II clinical trial (HESACOVID). Thromb Res 2020; 196: 359-366. DOI: 10.1016/j.thromres.2020.09.026.

18. Nadkarni GN, Lala A, Bagiella E et al. Anticoagulation, Bleeding, Mortality, and Pathology in Hospitalized Patients With COVID-19. J Am Coll Cardiol 2020; 76 (16): 1815-1826. DOI: 10.1016/j.jacc. 2020.08.041.

19. Klok FA, Kruip MJHA, van der Meer NJM et al. Confirmation of the high cumulative incidence of thrombotic complications in critically ill ICU patients with COVID-19: An updated analysis. Thromb Res 2020; 191: 148-150. DOI: 10.1016/j.thromres.2020.04.041.

20. Maatman TK, Jalali F, Feizpour C et al. Routine Venous Thromboembolism Prophylaxis May Be Inadequate in the Hypercoagulable State of Severe Coronavirus Disease 2019. Crit Care Med 2020; 48 (9): e783-e790.
21. Poggiali E, Bastoni D, Ioannilli E, Vercelli A, Magnacavallo A. Deep Vein Thrombosis and Pulmonary Embolism: Two Complications of COVID-19 Pneumonia? Eur J Case Rep Intern Med 2020; 7 (5): 001646. DOI: $10.12890 / 2020 \_001646$.

22. Tisoncik JR, Korth MJ, Simmons CP et al. Into the eye of the cytokine storm. Microbiol Mol Biol Rev 2012; 76 (1): 16-32.

23. Wong CK, Lam CWK, Wu AKL et al. Plasma inflammatory cytokines and chemokines in severe acute respiratory syndrome. Clin Exp Immun 2004; 136 (1): 95-103.

24. Levi M, van der Poll T. Coagulation and sepsis. Thrombosis Res 2017; 149; 38-44.

25. Schmitt FCF, Manolov V, Morgenstern J et al. Acute fibrinolysis shutdown occurs early in septic shock and is associated with increased morbidity and mortality: results of an observational pilot study. Ann Intensive Care 2019; 9 (1): 19.

26. Shi C, Wang C, Wang H et al. The Potential of Low Molecular Weight Heparin to Mitigate Cytokine Storm in Severe COVID-19 Patients: A Retrospective Clinical Study. Clin Transl Sci 2020; 13 (6): 1087-1095. DOI: $10.1111 /$ cts. 12880 .

27. Yormaz B, Ergün D, Tülek B, Ergün R, Arslan U, Kanat F. The impact of the "low molecular weight heparin" administration on the clinical course of COVID-19 disease. Turk J Med Sci 2020. DOI: 10.3906 / sag-2006-184.

28. Tang N, Li D, Wang X, Sun Z. Abnormal coagulation parameters are associated with poor prognosis in patients with novel coronavirus pneumonia. Journal of Thrombosis and Haemostasis Apr; 18 (4): 844-847. DOI: $10.1111 /$ jth. 14768 